\title{
The Effectiveness of the Semantic Concept Map Method in Concept Teaching to Students with Autism Spectrum Disorders
}

\author{
Fatih KOÇAK ${ }^{1} \&$ Hakan SARI ${ }^{2}$ \\ ${ }^{1}$ Necmettin Erbakan University, Ahmet Keleşoğlu Education Faculty, Special Education Department, Konya, \\ Turkey \\ ${ }^{2}$ Necmettin Erbakan University, Special Education Department, Konya, Turkey \\ Correspondence: Fatih KOÇAK, Necmettin Erbakan University, Ahmet Keleşoğlu Education Faculty, Special \\ Education Department. Konya, Turkey. E-mail: fatihkocak77@gmail.com
}

Received: May 14, $2021 \quad$ Accepted: June 19, $2021 \quad$ Online Published: June 24, 2021

doi:10.5539/jel.v10n4p170 URL: https://doi.org/10.5539/jel.v10n4p170

\begin{abstract}
This study aimed to examine the effectiveness of the semantic concept map method in teaching the family concepts of life studies lessons to students with Autism Spectrum Disorder. A multiple probe model with probe phase between subjects, one of the single-subject research methods, was used. The subjects of the study are 10-year-old three boys diagnosed with ASD. Inter-observer reliability and implementation reliability data were also collected in the study. Graphical analysis of the obtained data was made. As a result of the research, it was revealed that the semantic concept map method was effective in teaching the concepts within the theme of our family to students with Autism Spectrum Disorder.
\end{abstract}

Keywords: Autism spectrum disorder, concept teaching, semantic concept map method, single-subject research, multiple probe model, special education

\section{Introduction}

Students with Autism Spectrum Disorder (ASD) have difficulty remembering and using verbal and abstract words/information and it is known that they learn through visual presentations rather than through audio inputs (Tekin İftar \& Değirmenci, 2014). Students with ASD have limited or not limited verbal language skills, reading problems, attention deficit, or severe behavioral problems, and also it is known that they have difficulty in concretizing and learning abstract concepts in many lessons (Patton \& Bailey, 2013). The difficulties they show in focusing as required by the stimuli presented to them and in comprehending the characteristics of the stimuli cause them to have problems in establishing a connection between language and thought semantically (Sucuoğlu, 2010). It is stated that if functionalism is absent in the teaching of stimuli with visual support systems while organizing the mental processes of students with ASD, it will be problematic for the development of skills such as self-organization in the future (McClannahan \& Krantz, 1999). For this reason, it is emphasized that teaching studies with students with ASD should be supported with visual elements (Rao \& Gagie, 2006; Broun, 2004; Kimball, Kinney, Taylor, \& Stromer, 2003; Dettmer, Simpson, Myles-Smith, \& Gantz, 2000).

Visual Support Systems help students with ASD to exhibit, rank, and choose skills such as social adaptation, daily life, self-care, home and leisure management (McClannahan \& Krantz, 1999; Rao \& Gagie, 2006). Janzen (1996) stated the importance of teaching students with ASD with visual support systems (a) seeing everyone as a part of the communication system (b) helping students with ASD to develop their attention (c) directing students with ASD towards their goals (d) making abstract concepts more concrete (e) helping students with ASD to express their feelings and thoughts. Besides, in the relevant literature, visually presented clues are more effective than the verbal cues traditionally presented to students with ASD; It is stated that transitions between activities/goals facilitate learning and visual support systems are effective in implementations (Maguire, 2005; McClannahan \& Krantz, 1999). In this context, it is emphasized that to prevent difficulties experienced in teaching abstract concepts to students with ASD, emphasis should be placed on visualization of concepts in individual or group teaching, and creating concept networks and maps (Patton \& Bailey, 2013).

Concepts are the building blocks of mental processes such as thinking, relating, imagining, and making sense (Özyürek, 1984). Concepts are defined as a form of knowledge/structure representing the changeable common 
features of different objects and phenomena (Morris, 2002). They are mental categories used to classify people, objects, or events (Koçak, 2011). While the objects that make up the world are separated or defined by using their properties that differ according to each other, experiences become conceptualized by transforming into certain values over time. On the other hand, there are concepts produced for many events that cannot be controlled, and emotions, intuitions, and other factors are effective in the emergence and development of such concepts. Whether it includes concrete reality or abstract things, most of the concepts are indicators of the communication established with the world (Girgin, 2006). It is also a set of criteria that reveal what will be included in a category or what will be excluded from this category (Özyürek, 2009). Concept learning starts from the moment the individual is born and concept learning continues everywhere in daily life. School, on the other hand, ensures that concept teaching is carried out within the plan, and since the Social Studies lesson includes concepts that students will need in daily life. The Life Studies course is designed for children to get to know themselves, the society and the world they live in (Ministry of National Education, 2009). Today, the Life Studies course is included as a pivotal course in the first three grades of primary school. With this course, children have the opportunityto examine natural and social environment and it also provides the child to know himself and his family, to understand the environment and the events occurring in the environment, to find better ways of living, to know the places of the objects in the environment and how to use them (Şahin, 2009; Yıldı, 2009). It helps the child to know himself both psychologically and physiologically and to make sense of his environment (Kabapınar \& Özkan, 2012). It is more functional to teach social and subjects in the first three grades of primary school (Ersoy \& Kılınç, 2013; Bilasa et al., 2016; Aktepe \& Yalçınkaya, 2016).

The themes in this course should be introduced to students. Life studies lesson is very important in terms of preparing students for life and enabling them to learn and use various concepts to overcome the difficulties they encounter. Students with ASD can get to know the members of the family and be aware of the distinct features of these individuals with the Life Studies course. However, students with ASD have visual and abstract thinking difficulties. Therefore, it is very important to visualize the knowledge and skills to be taught (Grandin, 2005). The use of pictorial stimuli in the teaching process makes learning easier. Considering that students with ASD have difficulty in functionally organizing their acquired concepts, concept maps are needed in teaching abstract concepts to students with ASD and developing their vocabulary. Through the concept maps, the cognitive structure formed by the student for a certain area is revealed visually (Şimşek, 2006; Şen \& Özgün-Koca, 2003). Semantic Concept Maps included in Concept Maps were created to find solutions to the problems of students who have learning difficulties about creating vocabulary and establishing relationships between these words. It is based on teaching the concepts related to each other together. It makes it easier to organize information within a topic, to learn meaningfully, to understand new topics/concepts, to organize topics, to understand information structures, to detect misconceptions and misleadings. It helps train the brain. It makes it easier to remember. It can be used as a summary and repetition tool (Brinkmann, 2007).

When the relevant literature is examined, it is seen that there are various research results on the use of concept teaching maps. In his research, Vayiç (2008) investigated the effect of Direct Instruction Method and Schematic Editor Instruction on the achievement level of students with intellectual disabilities in Life Studies teaching and concluded that Instruction with Schematic Organizers is more effective in teaching Life Studies to students with intellectual disabilities than Direct Instruction. Kinchin (2014) stressed that teachers should be clear about the benefits of mapping activity and should convey the information to the students for effective learning. Studies by Vadlapatla, Kaur and Zhao (2007), Aziz and Jair (2009), and Jayaraman (2009) also revealed that the use of concept maps facilitated the learning process and was able to enhance students' achievement significantly. Therefore, literature review of past studies conducted on the effect of concept maps indicated the positive effects of the method on students' understanding, achievement, problem solving, team collaboration, motivation, attitude, and interest in learning (Kinchin, 2014). Several studies have also indicated that the utilization of concept maps enhances students' interest in learning. Findings by Chiou (2008) showed that $84 \%$ of the students in the study felt that they liked using concept mapping to assist them in learning accounting. Alkahtani (2009), in his research, investigating the effect of creative studies applied on hyperactive students on the complexity of concept maps, revealed that students in the group where creative activities were applied drew more complex concept maps. Fisher (1990) tried to reveal the similarities and differences of concept maps and semantic networks in his study named "Semantic Network" in which he explained the semantic concept maps. The features of semantic networks are (a) a clear and general overview, (b) holistic, (c) all connections are visible at the same time, (d) they are homogeneous representatives of reality (e) help both the teacher in teaching and the student in learning. As a result of this study, the researcher emphasized the importance of using semantic concept maps and suggested that they should be used in teaching. Studies emphasizing the necessity of the visual system in supporting the concept of teaching special needs students was very new and limited in Turkey (Güzel-Özmen, 2006; 
Güzel-Özmen et al., 2002). The researchers gave examples of the use of schematic organizers in life studies, social studies, and science teaching. Özmen (2009) explained how to prepare and use schematic organizers in Science, Social Studies, and Life Studies lessons.

It is emphasized that purely behavioral teaching and research that has been continuing for many years in the field of special education has become limited in contributing to the development of this field (Birkan, 2009). It has become inevitable to adapt and apply the methods used in general education, as well as the methods used in special education, especially in inclusion/integration studies, regarding individuals with special education needs. Similar to the innovations in general education, teaching studies in the field of autism are in the process of diversification. In this diversification process, the use of concept maps in the field of autism is also included. Therefore, this study aimed to examine the effectiveness of the semantic concept map method in teaching the concepts of our family theme in life studies lessons to students with ASD.

For this purpose; Answers were sought to questions:

Is the use of semantic (semantic) concept maps effective in teaching autistic children the concepts within the theme of our family in the life studies lesson, in gaining students the concepts of showing, saying, substituting, matching, photo placement and picture placement?

\section{Method}

\subsection{Research Model}

Among the research designs with a single subject, a "multiple probe model with probe phase between subjects" was preferred. The reason for choosing a single-subject research model in the study is that the individual characteristics of students with moderate and severe autism are different and the generalizability problems of studies with individuals with autism. In addition, it will not be possible to reach a large number of individuals with autism and to conduct teaching activities together. To determine the effectiveness of the inter-subject multiple probe model, continuous baseline data collection was performed for the first subject, while the probe data were collected only in the first session for the other subjects. The research model and application steps are visualized in Table 1.

Table 1. Research process

\begin{tabular}{|c|c|c|c|c|c|c|c|}
\hline 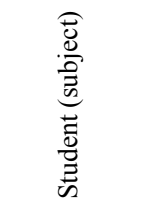 & 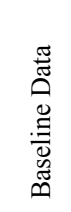 & 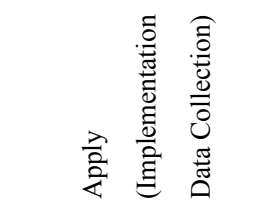 &  & 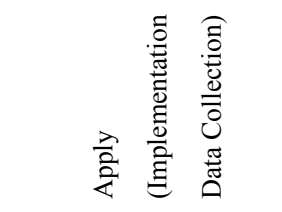 & 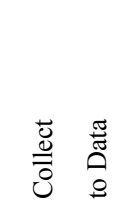 &  & 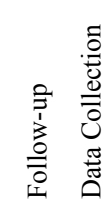 \\
\hline Student I & $* * *$ & $* * * * * * * * * * * * * * * * * *$ & $* * *$ & & $* * *$ & & $* * *$ \\
\hline Student II & $* * *$ & & $* * *$ & $* * * * * * * * * * * * * * * * * * *$ & $* *$ & & $* * *$ \\
\hline Student III & $* * *$ & & $* * *$ & & $* * *$ & $* * * * * * * * * * * * * * * * *$ & $* * *$ \\
\hline
\end{tabular}

The implementation was initiated when the data collected for the first subject became stable. At this stage, baseline data were collected for the second subject and probe data for the third subject. The İmplementation phase requires the stability of the baseline data in the second subject, and the baseline data for the third subject is collected during the İmplementation phase of the second subject. When the determination for the second subject is reached, the Implementation is started for the third subject. In addition, in some sessions, monitoring data about other subjects are collected (Karcaali-Iftar \& Tekin, 1997).

\subsection{Implementation Process}

Before the implementation, the student (subject) to participate in the research, the preparation of the programs, the material supply, and the environment arrangements were made. In addition, the baseline levels of the students who participated in the study were determined. The implementation process consisted of at least 30 sessions for each student. Since the stable data were reached in 3 consecutive sessions in the pre-teaching evaluation sessions with 
Subject 1, teaching sessions (18 sessions) were initiated, and post-teaching evaluation was carried out at the end of the teaching sessions. Pre-teaching evaluation sessions with Subject 3 were started after Subject 2 passed to teaching sessions, and pre-teaching evaluation was made for 5 sessions. After obtaining the stable data (sessions 3 , 4, and 5), the teaching sessions (17-19) were started and the teaching process ended with 3 sessions of post-teaching evaluation.

In the process of preparing individualized teaching materials related to the teaching process, the Ministry of National Education Primary Education Life Studies Lesson 1, 2, 3. The "Our Family" theme in the Classes Education Program (2004) and the Education Program for Children with Autism prepared by the Ministry of National Education was used (http://orgm.meb.gov.tr, 2010). The concepts within the theme of our family in the program and the order of these concepts have been determined. Information was requested from the families of the students about the determined concepts. The following steps were followed during the preparation of activity materials to be used in individualized teaching materials based on our family theme concepts semantic concept map teaching. First step: A color photograph was requested from three families of $15 \times 20 \mathrm{~cm}$ in which all family members were together. Second step: A 5x7cm passport photo of the family members (Father / Mother / Brother / Sister and the Student Himself) was requested from the three participating students. Third step: Pictures of the three participating students themselves and the characteristics of their family members were created. Fourth step: The pictures of the families of the students participating in the study were colored with crayons. Fifth step: Colorless cardboards of $2 \mathrm{~mm}$ thickness were cut according to the size of the photographs and pictures created in the first and third steps. Sixth step: Photographs of family members and pictures of family members' characteristics are pasted on the cut cardboards. Seventh step: The cards created from photographs of family members and pictures of the characteristics of family members were covered with dejifix (colorless, transparent, durable tapes with one side adhesive). Eighth step: Magnet is affixed to the edges of the cards created in the sixth and seventh steps. Ninth step: To create the semantic concept map, a $120 \times 70 \mathrm{~cm}$ magnetized teacher board was drawn with rectangles in accordance with the dimensions of the photographs and pictures. Tenth step: Different from the line colors of the rectangles created on the teacher's board, colored intermediate lines showing the relationship between the rectangles were drawn. Eleventh step: The cards of the concepts that are within the theme of our family created in the ninth step and the previous steps were respectively performed under the gains in the measurement tools in the semantic concept map created on the teacher's board.

\subsection{Implementation Reliability}

To be used in the collection of implementation reliability data, the Instructional Activities with Semantic Concept Maps Implementation Reliability Form was prepared for the concepts mentioned in the Life Studies Lesson Our Family theme. Participant observer help was requested from another special education teacher working in the training center where the implementation was performed to determine the reliability of the implementation. The participant-observer was informed about the use of this form and the program being conducted. The participant-observer recorded the behaviors that the researcher had to do and whether he did or did not do during the implementation. In determining the reliability of the implementation, implementation reliability $=$ Number of Correct Response / Total Number of Reactions X 100 formula was used (Kurcaali-Iftar \& Tekin 1997). In this study, the implementation reliability was found to be $100 \%$.

During the study, a special education teacher working in the education center helped the reliability of the reactions of the students. The observer was informed about the teaching activities with Semantic Concept Maps, the Discrimination Measurement Tool, the measurement tool implementation instruction, and the registration procedures about the concepts mentioned in the Life Studies lesson Our Family theme. The researcher and the observer recorded simultaneously. The observer was seated in the same environment so that the student would not be affected. Inter-Observer Reliability = Division to the Total of Consensus Between Two Observers was found with the formula X 100 (Kurcaali-Iftar \& Tekin, 1997). The reliability among the observers in the study was determined as $95 \%$.

The reliability (inter-observer and implementation reliability) data of the study were collected by a Ph.D. student in the field of Education Programs and Teaching at Selcuk University Institute of Educational Sciences and a teacher who has been working in the field of special education (education of children with ASD for 2 years) for 6 years.

\subsection{Analysis of Implementation Data}

In the research, the data obtained through the teaching work with the students were analyzed by graphical analysis. Baseline data to determine the pre-teaching performance levels of students, the teaching process to determine the effect level of the implementation, and post the implementation data to show the effectiveness of the 
implementation after the teaching process was presented. The data obtained at the end of the research were analyzed on a line chart. On this chart, the baseline level, teaching process, and post-teaching data were processed. In the Multiple Probe Model between subjects, the linear curves obtained at the baseline level, during implementation, and after the implementation were compared with the linear curves, and they provided information about whether the method used in the implementation was effective (Kurcaali-İftar \& Tekin, 1997). The frequency values representing the correct answers of the student were converted into percentages and graphical expressions were created.

\subsection{Study Group}

Written approvals of the families were obtained for the participation of the students in the study. Participating students were not subjected to a teaching process related to the concepts that were previously mentioned in the "our family" unit. At the same time, the participant students (subjects) have not participated in any activity related to the use of semantic concept maps before. Before collecting baseline data, it was stated that the study of participant students' unit concepts of "our family" is important for the family. Table 2 describes the three subjects (students) participating in the research and their distinctive characteristics.

Table 2. Three subjects (students) participating in the study and their distinctive characteristics

\begin{tabular}{|c|c|}
\hline Subject & Participating Student (Subject) Characteristics \\
\hline Subject 1(R.B.) & $\begin{array}{l}\text { He is a } 10 \text {-year-old boy diagnosed with ASD. He is one of the two boys in the family and is the second child in the family. } \\
\text { Of the communication skills, the recipient can fulfill the language skills and has expressive language skills partially. The } \\
\text { student did not receive any training until he came to the Dependent OÇEM he attended. He had been continuing education } \\
\text { since September 2009. There is no obvious problem behavior and has toilet control. The student does not have literacy } \\
\text { skills. }\end{array}$ \\
\hline Subject 2(H.Ç.) & $\begin{array}{l}\text { He is a } 10 \text {-year-old boy diagnosed with ASD. He is one of the three children of the family and is the youngest member of } \\
\text { the family. He has two older sisters. Of the communication skills, the recipient can fulfill the language skills and has } \\
\text { partial expressive language skills. The student has received various training till coming to the Dependent OÇEM he } \\
\text { attends. After being diagnosed at the age of } 4 \text {, he received training in Private Special Education Institutions. Since } \\
\text { September } 2009 \text {, he has been continuing his education in OÇEM. There is no obvious problem behavior and has toilet } \\
\text { control. The student does not have literacy skills. }\end{array}$ \\
\hline Subject 3(T.B.Ü) & $\begin{array}{l}\text { He is a } 10 \text {-year-old boy diagnosed with ASD. He is one of the three children of the family and is the youngest member of } \\
\text { the family. He has two older brothers. Of the communication skills, the recipient can fulfill the language skills and has } \\
\text { partial expressive language skills. The student has received various training until coming to the Dependent OÇEM he } \\
\text { attends. After being diagnosed at the age of } 3 \text {, he received training in Private Special Education Institutions. Student } 3 \\
\text { studied in two different cities. Since September } 2009 \text {, he has been continuing his education in Konya Dependent OÇEM. } \\
\text { There is no obvious problem behavior and has toilet control. The student does not have literacy skills. }\end{array}$ \\
\hline
\end{tabular}

The criteria for the students to participate in the study to have various prerequisite skills are taken into account. These prerequisite skills are as follows: a) the ability to show by pointing, b) to follow the instructions consisting of at least two words, c) the absence of any health problems that prevent him from participating in the study, d) the ability to wait for 5 minutes when left alone, e) ability to distinguish people from each other.

\subsection{Data Collection Tools}

In this section, there are explanations about Concept Measurement Tools used in the collection of research data, Guidelines for Using Concept Measurement Tools and Concept Measurement Tools Registration Schedules, scoring Concept Measurement Tools, determining performance level, and implementation of Concept Measurement Tools. Criterion-dependent measurement tools were developed to determine the performance levels of the student with ASD in understanding the concepts of family, mother, father, and sibling, before and after the education, which are included in the theme of "our family".

Table 3. İmplementation of measuring tools

\begin{tabular}{llll}
\hline Tool & $\begin{array}{l}\text { Baseline Data } \\
\text { Collection }\end{array}$ & $\begin{array}{l}\text { Implementation Phase Data } \\
\text { Collection }\end{array}$ & $\begin{array}{l}\text { Post-Implementation Data } \\
\text { Collection }\end{array}$ \\
\hline Show Measure Tool & $\mathrm{T} 1(1-5)$ & $\mathrm{T} 1(6-20)$ & $\mathrm{T} 1(21-23)$ \\
Tell Measure Tool & $\mathrm{T} 2(1-5)$ & $\mathrm{T} 2(6-20)$ & $\mathrm{T} 2(21-23)$ \\
Replacement Measure Tool & $\mathrm{T} 3(1-5)$ & $\mathrm{T} 3(6-20)$ & $\mathrm{T} 3(21-23)$ \\
Match Measure Tool & $\mathrm{T} 4(1-5)$ & $\mathrm{T} 4(6-20)$ & $\mathrm{T} 4(21-23)$ \\
Photo Placement Measure Tool & $\mathrm{T} 5(1-5)$ & $\mathrm{T} 5(6-20)$ & $\mathrm{T} 5(21-23)$ \\
Image Placement Measure Tool & $\mathrm{T} 6(1-5)$ & $\mathrm{T} 6(6-20)$ & $\mathrm{T} 6(21-23)$ \\
\hline
\end{tabular}


For this purpose, the measurement tool for showing family theme concepts in the semantic concept map (T1), the measurement tool for expressing family theme concepts in the semantic concept map (T2), the measurement tool for replacing family theme concepts in the semantic concept map (T3), and the matching of family theme concepts in the semantic concept map. tool (T4), family theme concepts in semantic concept map photo placement measurement tool (T5), and family theme concepts picture placement measurement tool (T6) in semantic concept map were developed. Concept measurement tools consist of instructions, questions related to instructions, and criteria to determine the gains by analyzing the concepts of our family theme. Also, an observation form was prepared to determine the students' behaviors related to the activities in the teaching process.

The implementation of T1, T2, T3, T4, T5, T6 measurement tools developed in the study is presented in Table 3 .

\subsection{Measuring and Scoring Tool Record Chart}

The aims gained by the students with ASD before, during, and after the education, who were taken to the teaching of the concepts mentioned in the Life Studies lesson "Our Family" theme, were recorded in the registration section created in the last part of the measurement tool. In this enrollment chart, there are columns in which the name and surname of the student, the date of the measurement were made, the correct answers/reactions of the students (+), the wrong or inaccurate reactions, or the situations in which they were unresponsive were recorded as (-). In return for the correct answers/reactions of the students in the measurement tool regarding the concepts in the Life Studies lesson "Our Family" theme 1, and 0 (zero) is given in return for his/her wrong or incorrect answers/responses or unresponsiveness. Correct answers/responses were accepted by the students as meeting the specified criterion.

An observation form was prepared to determine the students' behaviors during the activities in the concept teaching sessions carried out individually with the students. The observation form consists of eight items and for each item, there is a triple scale of "yes", "no" and "sometimes". In all sessions with students, an observation form was used and student behaviors were recorded in the relevant column. The behaviors observed in the student were recorded as $(+)$ according to the observation status.

\section{Findings}

In this section, findings/comments based on students' implementation results and findings/comments based on family opinions about the use of concepts in the theme of our family in the semantic concept map are included.

Figure 1: The levels of the subjects in the study group to show the concepts of our family theme in the semantic concept map and show the beginning and implementation levels, total probe, and follow-up sessions related to their speaking skills. 


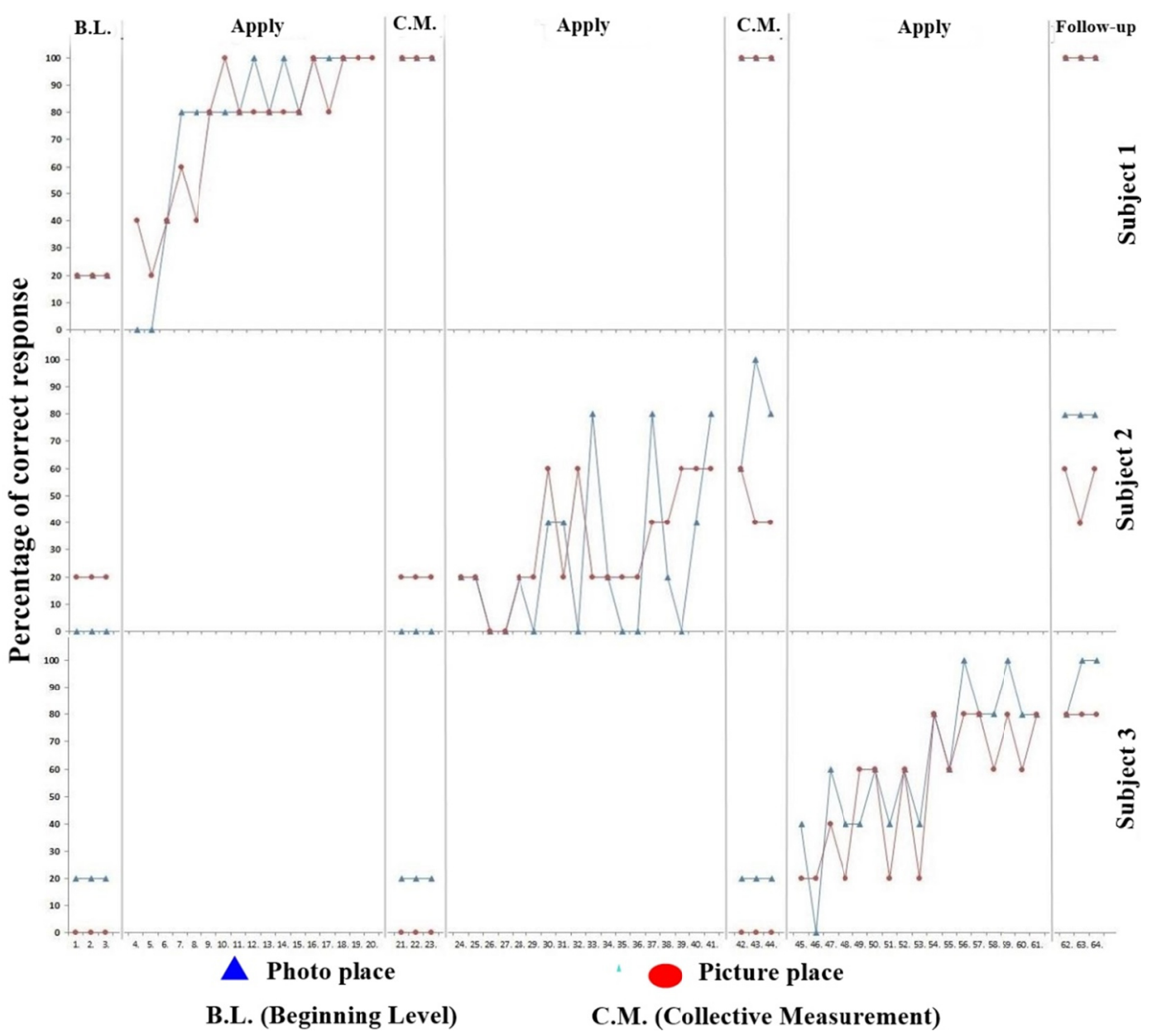

Figure 1. The levels of the subjects in the study group to show the concepts of our family theme in the semantic concept map and show the beginning and implementation levels, total probe, and follow-up sessions related to their speaking skills

When the levels of showing the concepts of the "Our Family" theme in the semantic concept map were examined (Figure 1), it was seen that the first student at the baseline level has $20 \%$ of the acquisitions in the measurement tool. Looking at the teaching process carried out with the semantic concept map teaching material, it was found that it was the same as the baseline data in the fifth session; it increased to $60 \%$ by the seventh and eighth sessions; In the ninth session, it is seen that he achieved the gains $100 \%$. In the tenth session, while the rate of achieving the acquisitions in the measurement tool decreased to $60 \%$, the rate of achieving the gains in the measurement tool from the eleventh to the sixteenth session was $80 \%$. After the seventeenth session, it was observed that the student gained all the expected gains $(100 \%)$ and showed stability. It can be said that the point reached by the first student at the end of the teaching process was higher than the beginning level of teaching, and there was a significant difference between the student's baseline level and the point at the end of the teaching process. It was observed that the student progresses in the acquisitions during the teaching process. On the other hand, the data obtained with the measurement tool of the level of showing the concepts in the theme of our family in the semantic concept map were parallel to the data obtained at the end of the teaching process.

With the baseline level of the second student, the percentage of achieving the gains until the sixth session varied between $0-20 \%$. The rate of achieving gain, which was $0 \%$ in the sixth session, increased by $40 \%$ in the seventh session and $80 \%$ in the eighth session. From the eighth session to the nineteenth session (the sixteenth teaching session), the rate of attainment continued to vary. From the nineteenth session until the twenty-first session, the rate of achieving the gain showed $80 \%$ stability. It can be said that the point reached by the second student at the end of the teaching process was higher than the baseline level of teaching, and there was a significant difference between the baseline level and the point at the end of the teaching process. It was observed that the student progresses in the acquisitions during the teaching process. The data obtained with the level measurement tool of 
showing the concepts in the theme of our family in the semantic concept map were in parallel with the data obtained at the end of the teaching process. Therefore, it can be said that teaching with semantic concept maps was effective in obtaining the concepts and related gains that were within the theme of our family.

The third student's baseline performance was $20 \%$, and this rate showed stability during three sessions. The rate of realizing the gains, which increased to $40 \%$ in the first session of the teaching process, maintained this stability until the tenth session. The rate of gain, which increased to $78 \%$ in the eleventh session, remained at the same level in the twelfth session. However, it fell to $60 \%$ in the thirteenth session. It was observed that all of the aims were achieved from the 14th session until the end of the teaching process and this stability continued in the post-teaching sessions. It can be said that the point reached by the third student at the end of the teaching process was higher than the baseline level of teaching, and there was a significant difference between the baseline level and the point at the end of the teaching process. It is observed that the student progressed in the acquisitions throughout the teaching process. The data obtained with the measurement tool of the display level of the concepts in the theme of our family in the semantic concept map were in parallel with the data obtained at the end of the teaching process.

When the semantic concept expression levels of the theme concepts of our family were examined, it was seen that the first student achieved $60 \%$ of the gains in the baseline sessions and the same determination continued throughout three sessions. While the same rate $(60 \%)$ was continuous in the first three sessions of the teaching process; in the fourth session, the rate of realizing the gains increased to $80 \%$. While it decreased to $60 \%$ in the fifth session, the same rate remained constant in six sessions. Looking at the seventh session, it was seen an increase to $80 \%$ again. This rate remained stable, including the eleventh session. In the twelfth session, all of the achievements were realized. However, it decreased to $80 \%$ in the thirteenth session. While the rate of achieving the gains was $80 \%$ in the 14th session, it was seen that all of the gains were realized in the fifteenth session and this situation continued decisively until the end of the teaching process. The same determination continued in all three post-teaching sessions. It can be said that the point reached by the first student at the end of the teaching process was higher than the starting level of teaching and there was a significant difference between the baseline level and the point at the end of the teaching process. It was observed that the student progresses in the acquisitions during the teaching process. The data obtained with the telling level measurement tool in the semantic concept map of the concepts that were within the theme of our family were in parallel with the data obtained at the end of the teaching process.

It was seen that the rate of the second student to realize the acquisitions before the baseline level is $0 \%$. While it was observed that the gains could not be achieved in the first, second, and third sessions of the teaching process, the rate of achieving the gains increased to $20 \%$ in the fourth session and the same rate continued in the fifth session. While it decreased to $0 \%$ in the sixth session, it increased to $20 \%$ in the seventh session and $40 \%$ in the eighth session, but there was an unstable increase in the rate of achieving the gains until the fifteenth session. It was seen that in the fifteenth session, all of the achievements were achieved and this situation continued steadily until the end of the teaching process. It was seen that the student achieved all of the gains in the post-teaching sessions. It can be said that the point reached by the second student at the end of the teaching process was higher than the baseline level of teaching, and there was a significant difference between the baseline level and the point at the end of the teaching process. It was observed that the student progresses in the acquisitions during the teaching process. On the other hand, the data obtained with the telling level measurement tool in the semantic concept map of the concepts that were within the theme of our family were in parallel with the data obtained at the end of the teaching process.

While it was observed that the third student could not achieve the gains in the baseline sessions, the rate of achieving the gains increased by $40 \%$ in the first session of the teaching process, $60 \%$ in the second session, and $80 \%$ in the third session. While the same rate was observed in the fourth session, ups and downs are observed in other sessions until the ninth session. The rate of $80 \%$ in the ninth session showed the same determination until the thirteenth session. It was seen that in the thirteenth session, all of the achievements were realized and the same determination continued until the end of the teaching process. The same determination was observed in all three post-teaching sessions. It can be said that the point reached by the third student at the end of the teaching process was higher than the baseline level of teaching, and there was a significant difference between the baseline level and the point at the end of the teaching process. It was observed that the student progresses in the acquisitions during the teaching process. The data obtained with the telling level measurement tool in the semantic concept map of the concepts that were within the theme of our family were in parallel with the data obtained at the end of the teaching process.

Figure 2: The level of showing the baseline, implementation, full probe, and follow-up sessions of the subjects in the study group regarding the substitution and matching skills of our family theme concepts in the semantic 


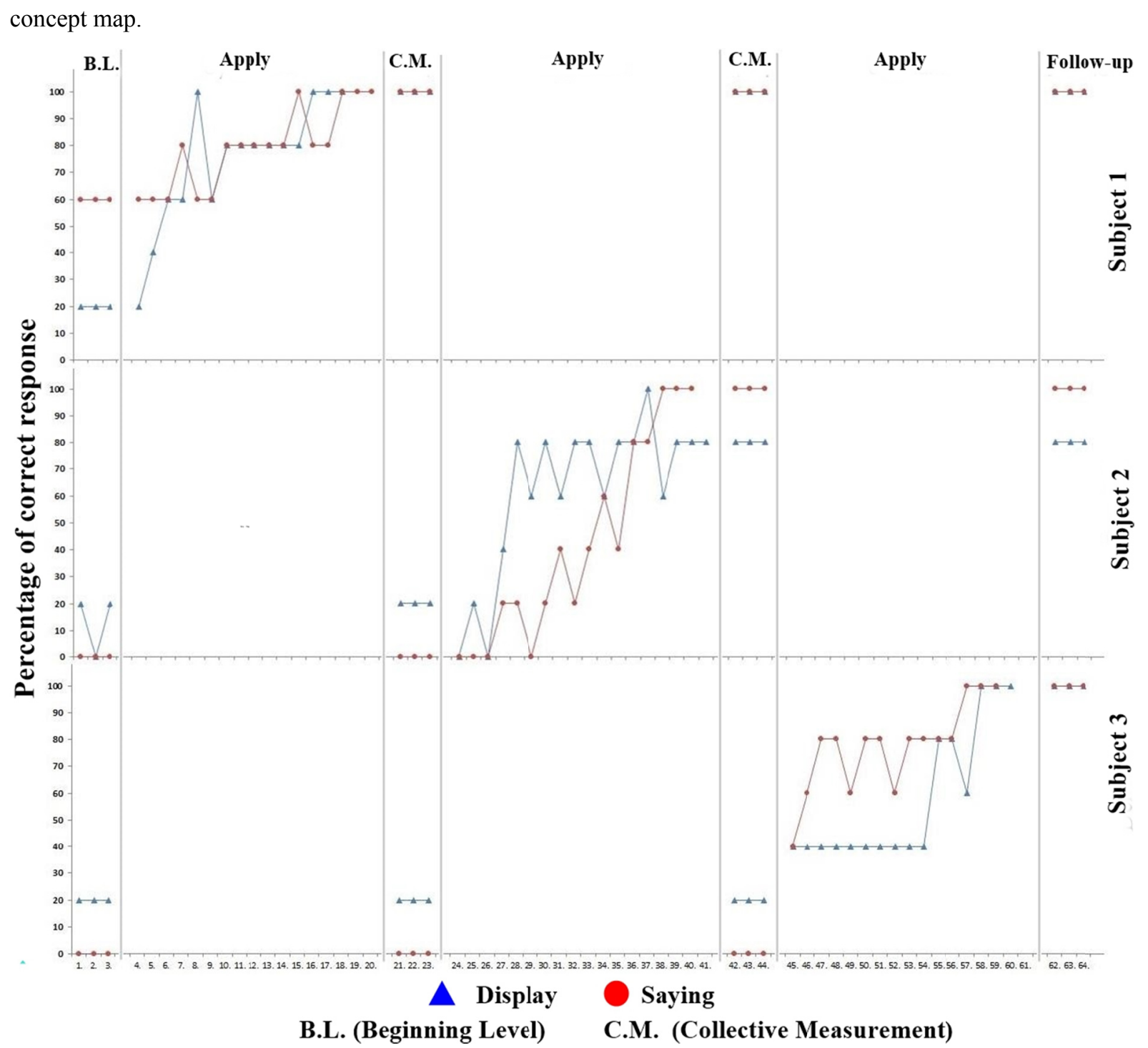

Figure 2. The level of showing the baseline, implementation, full probe, and follow-up sessions of the subjects in the study group regarding the substitution and matching skills of our family theme concepts in the semantic concept map

When Figure 2 was examined, the rate of achieving the gains in the baseline sessions of the first student is $40 \%$. While it was $40 \%$ in the first session, it increased to $60 \%$ in the second session and regressed to $40 \%$ in the third session. It was seen that there was an improvement to $60 \%$ in the fourth session and the same rate continued in the fifth session. Progress in achieving the gains continued until the seventh session, and it was seen that all of the gains were achieved in the seventh session. The decline in the eighth and ninth sessions remained at $80 \%$. It was seen that all of the achievements were realized since the ninth session and this stability continued until the end of the education. It was seen that all of the achievements were realized at the end of the teaching sessions. It can be said that the point reached by the first student at the end of the teaching process was higher than the baseline level of teaching and there was a significant difference between the baseline level and the point at the end of the teaching process. It was observed that the student progresses in the acquisitions during the teaching process. The level of substitution of the concepts in the theme of our family in the semantic concept map was in parallel with the data obtained at the end of the teaching process.

While the rate of the second student to realize the acquisitions in the pre-teaching sessions was $20 \%$, the student could not achieve the gains in the first of the teaching sessions. While there was a rapid increase of $40 \%$ in the second session, it decreased to $0 \%$ in the third session. While there was a sudden increase in the fourth session, the 
rate of realizing the gains was $60 \%$. It remained constant at $60 \%$ for the following three sessions. While progress and regressions were observed at varying rates until the sixteenth session; In the sixteenth, seventeenth, and eighteenth sessions, the rate of realizing the gains was $80 \%$. The rate of $80 \%$ in the first two of the end of teaching sessions was $100 \%$ in the third session. It can be said that the point reached by the second student at the end of the teaching process was higher than the starting level of teaching, and there was a significant difference between the baseline level and the point at the end of the teaching process. It was observed that the student progresses in the acquisitions during the teaching process. The level of substitution of the concepts in the theme of our family in the semantic concept map was in parallel with the data obtained at the end of the teaching process.

The third student could not achieve the gains in the baseline sessions. The rate of $20 \%$ in the first session of the teaching process was $60 \%$ in the third session. The regression to $40 \%$ in the fourth session did not remain constant, and the rate of achieving the gains in the fifth session was $80 \%$. The figure showed progress and regressions at varying rates. The student achieved all of the achievements in the seventeenth and eighteenth sessions and showed the same determination at the end of the teaching sessions. It can be said that the point reached by the third student at the end of the teaching process was higher than the beginning level of teaching, and there was a significant difference between the starting level and the point at the end of the teaching process. It was observed that the student progresses in the acquisitions during the teaching process. The level of substitution of the concepts in the theme of our family in the semantic concept map was in parallel with the data obtained at the end of the teaching process.

The rate of achievement of the first student in the pre-teaching baseline sessions was determined $40 \%$. Regarding the teaching phase, the rate of realizing the gains during six sessions starting from the first session was $60 \%$. It was seen that the rate increased to $80 \%$ in the seventh session. It was seen that in the ninth session, all of the achievements were realized and the rate remained constant until the end of the education. Likewise, it was seen that the rate of $100 \%$ continued in the three sessions after the instruction. It can be said that the point reached by the first student at the end of the teaching process was higher than the starting level of teaching and there was a significant difference between the starting level and the point at the end of the teaching process. It was observed that the student progresses in the acquisitions during the teaching process. The data obtained with the matching level measurement tool in the semantic concept map of the concepts that were within the theme of our family were parallel to the data obtained at the end of the teaching process.

It was seen that the second student realized the gains by $20 \%$ in the baseline sessions. Regarding the teaching stage, it was seen that there were sudden declines and improvements in the rates of achieving the gains. Fluctuations between $20 \%$ and $40 \%$ in the first four sessions; the rate of realization of the gains falling to $0 \%$ in the fifth session; rapid progress to $80 \%$ in the sixth session; It was seen that there was a rapid decline to $0 \%$ in the seventh session. Progress, which increased to $40 \%$ in the eighth session, reached $80 \%$ in the ninth session. In the fifteenth session, it was seen that all of the achievements were realized and there was constant stability in the proportions until the end of the teaching. All of the achievements were achieved in all three sessions at the end of the teaching. It can be said that the point reached by the second student at the end of the teaching process was higher than the baseline level of teaching, and there was a significant difference between the baseline level and the point at the end of the teaching process. It was observed that the student progressed in the acquisitions throughout the teaching process. The data obtained with the matching level measurement tool in the semantic concept map of the concepts that were within the theme of our family were in parallel with the data obtained at the end of the teaching process.

When the situation of the third student was examined, it was seen that the student did not achieve the gains in the baseline sessions and the first three sessions of the teaching process. It was seen that progress up to $40 \%$ in the fourth session remained constant in the fifth and sixth sessions. In the next three sessions, the rates varied between $20 \%$ and $40 \%$. In the eleventh session, the rate of realizing the gains progressed from $20 \%$ to $80 \%$. It varied from a regression of up to $40 \%$ in the next four sessions to an improvement of $80 \%$ in the fourteenth session. The student achieved all of the achievements in the fifteenth session and this rate continued until the end of the teaching and after the teaching sessions. It can be said that the point reached by the third student at the end of the teaching process was higher than the beginning level of teaching, and there was a significant difference between the baseline level and the point at the end of the teaching process. It was observed that the student progressed in the acquisitions during the teaching process. The data obtained with the measurement tool of the display level of the concepts in the theme of our family in the semantic concept map were in parallel with the data obtained at the end of the teaching process.

Figure 3: The levels of the subjects in the study group to show the concepts of our family theme in the semantic concept map regarding the skills of photo placement and picture placement in the baseline, implementation, full probe, and follow-up sessions. 


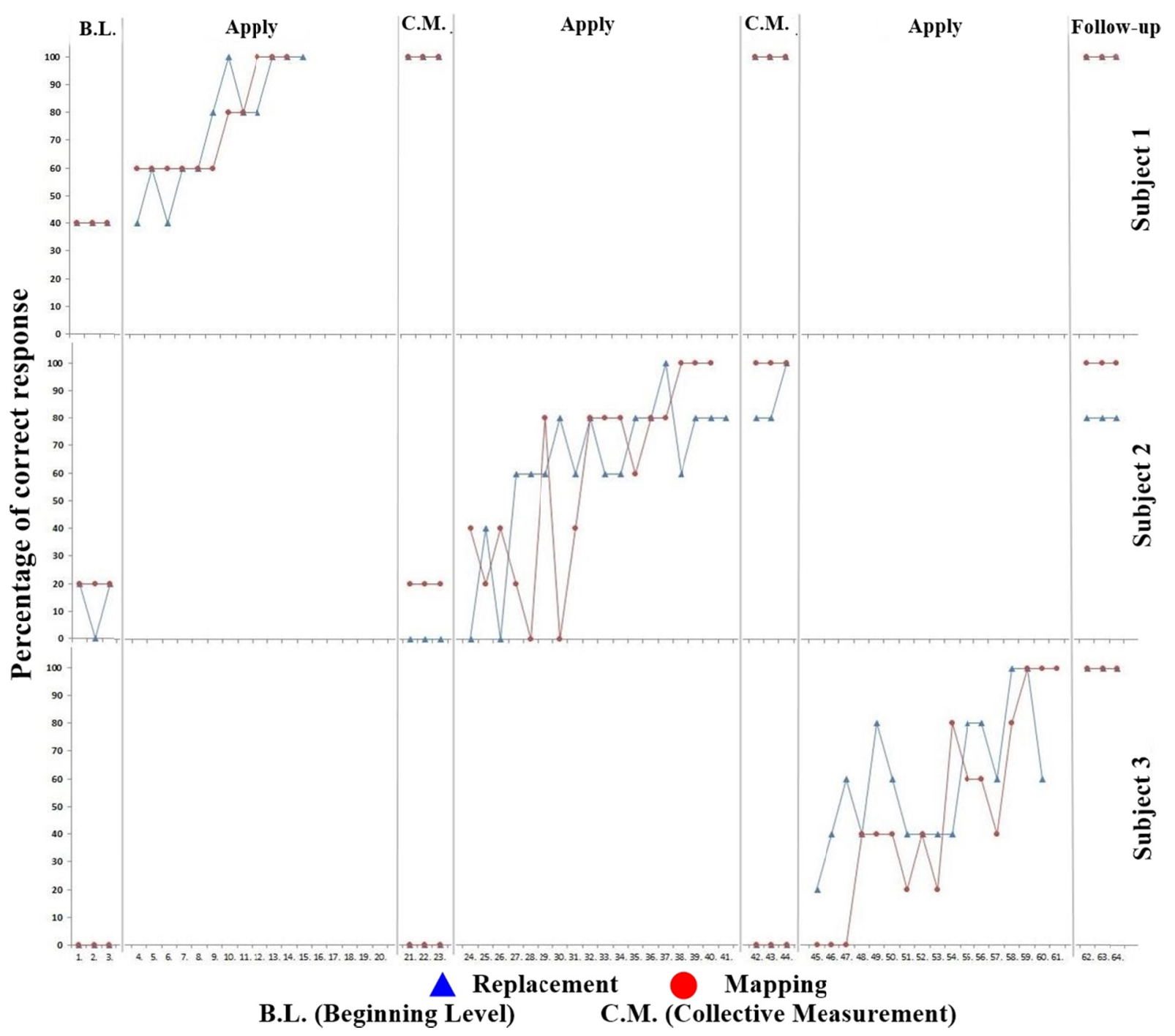

Figure 3. The levels of the subjects in the study group to show the concepts of our family theme in the semantic concept map regarding the skills of photo placement and picture placement in the baseline, implementation, full probe, and follow-up sessions

When Figure 3 was examined, it was seen that the first student achieved $40 \%$ of the expected gains in the baseline sessions; It was seen that the teaching process could not achieve the gains in the first two sessions. Progress was up to $40 \%$ in the third session and $80 \%$ in the fourth session. The $80 \%$ rate that continued until the eighth session was $100 \%$ in the ninth session. In the sessions that last until the thirteenth session, progress and regressions were observed in the rate of achievement of achievements. In the thirteenth session, the student achieved all of the gains and this rate remained constant until the end of the post-teaching sessions. It can be said that the point reached by the first student at the end of the teaching process was higher than the beginning level of teaching, and there was a significant difference between the baseline level and the point at the end of the teaching process. It was observed that the student progresses in the acquisitions throughout the teaching process. The data obtained by the photo placement level measurement tool in the semantic concept map of the concepts that were within the theme of our family were in parallel with the data obtained at the end of the teaching process. While the second student could not achieve the expected gains in the baseline level sessions, it was seen that there were rapid ups and downs and changing rates throughout the teaching process. While the student could not achieve all of the gains in any of the teaching sessions; realized all of the achievements in the second session after teaching. However, it regressed to $80 \%$ in the third session. Despite the unstable ratios in the figure, it can be said that the point reached by the student at the end of the education was higher than the beginning level of teaching and there was a significant difference between the starting level and the point at the end of the teaching process. It was observed that the student 
progressed in the acquisitions throughout the teaching process. The third student achieved gains of around $20 \%$ in the baseline sessions. While the progress was $40 \%$ in the first session of the teaching, the student could not achieve the expected gains in the second session. Throughout the teaching process, the rates fluctuated with ups and downs. $80 \%$ of the gains in the first session after the instruction; In the second and third sessions, all of the achievements were realized. Despite the unstable ratios in the figure, it can be said that the point reached by the student at the end of the education is higher than the beginning level of teaching and there was a significant difference between the baseline level and the point at the end of the teaching process. It was observed that the student progressed in the acquisitions throughout the teaching process.

\section{Conclusion, Discussion, and Implications}

In this study, the effectiveness of semantic concept maps limited to the Life Studies Lesson Our Family Theme was realized and it was tried to be revealed that it was effective in concept learning for students with ASD. According to the findings obtained from the research, the use of Semantic Concept Maps in teaching the concepts in the Life Studies Lesson "Our Family" theme was effective in all the students with ASD at the level of showing, saying, matching, replacing, photographing and painting. Considering the effectiveness of the method in all areas that constitute the research sub-problems, this research is also supported by the findings that it gives effective results in all lessons and subjects in the studies conducted in the world and Turkey. The fact that different (individualized) teaching materials in semantic concept maps used in research give similar positive results to students creates the impression that semantic concept maps can also be effective in teaching other concepts, subjects, and skills. When the relevant literature is examined, many studies are reporting that the use of concept maps both in other themes of the Life Studies lesson and in other lessons is effective. While Güzel-Özmen (2009) reveals the effectiveness of concept maps and other schematic organizers in teaching reading and writing in Turkish lessons, Ruiz-Prima and Shauelson (1996) state that the concept map used in Science is effective. Balım, Aydin and Evrekli (2006) emphasized the importance of the use of Mind and Concept Maps in the Science course.

Jackson ve Hanline (2020) their studies learning science is important for students with autism spectrum disorder (ASD), as knowledge of science allows students to understand their natural world, and science, technology, engineering, and mathematics (STEM) education is increasingly emphasized in schools. Reading to learn science is, therefore, a vital skill in today's schools for all students. Using a singlecase reversal design, this study evaluated the effectiveness of Reading to Engage Children with Autism in Language and Literacy (RECALL; a shared reading intervention) combined with a concept map on the ability of young children with ASD to answer comprehension questions from science text. Two 5-year-old boys with ASD participated in this study. Results indicated that RECALL combined with a concept map was effective in increasing participants' correct responding to comprehension questions from science text. Implications for intervention and research are discussed. The results of this research are similar to those of Jackson and Hanline (2020). Huang and Lee (2020) in their study Sequence Learning Strategy based on socialb stories and designs a sequential social story situation board game system using Augmented Reality (AR) technology (SL-ARS). This study recruited three 7-9-year-old children with autism and observed the explicit behavior of autistic children during the operation of SL-ARS by microbehaviors for video coding. After performing the SL-ARS system in an autism case, we found that autistic children performed well in understanding social situations and responding to other people's physical behavior, as they can understand the sequence of social situations from SL-ARS, and observe the social reciprocity of social situations through the structured visual learning framework. In the process of playing, AR can improve the learning motivation and operating pleasure of autistic children to understand the social situation, and construct the relationship of social cognition and social reciprocity of autistic children into the context of social situations. This interactive learning gives them the social skills and context to develop social situations, and we believe that AR technology combined with the sequential social context is helpful to train autistic children's social reciprocal ability. The results of this research are similar to those of Huang ve Lee (2020). Lee, Chen, Wang and Chung (2018) in their study reported that there is a lack of appropriate instructional scaffolds in AR applications to help students organize learning materials. Therefore, in this study, we use AR combined with concept map (CM) strategy as a training tool to focus on the standard nonverbal social cues to teach children with ASD how to appropriately reciprocate when they greet others. The learner can integrate the AR with CM strategy to visually conceptualize the social scenarios in a tabletop role-play training platform. Single-subject research with a multiple-baselines across-subject design was used in this study. Our results showed substantial increases in the children's target responses during the intervention phases compared with the baseline phases. Generalization probes were administered during baseline (4-8 sessions for $0.5-1$ month), intervention (10 sessions for 1.2 months), and maintenance phases (4-8 sessions for $0.5-1$ month) to assess the generalization and maintenance of learned skills. The three-phase test data suggest that the AR with CM intervention was 
moderately effective in teaching the target greeting responses to children with ASD. The practical and developmental implications of the findings are discussed. The results of this research are similar to those of Lee et al. (2020).

The fact that different (individualized) teaching materials in semantic concept maps give similar positive results to students creates the impression that semantic concept maps can also be effective in teaching other concepts, subjects, and skills. Similarly, in addition to studies showing that it is effective in individual teaching studies, finding evidence that it is effective in both normal individuals and disabled individuals in group teaching studies creates a wide range of action in choosing samples for studies to be conducted in this field. Visualization of information has been the subject of research for many years. Most of the studies conducted have revealed that visual information is easier to learn than verbal information and is more permanent. It has been observed that concept maps, one of the tools of visualization of knowledge, provide permanent learning, help students with learning difficulties, and enable students to perceive complex structures as a whole. Researchers found that concept maps allow teachers to observe the knowledge students have in a subject area and to distinguish which students need more help; They are united in the view that it helps to compromise meaning and is effective in following their development through the eyes of the student (Canas et al., 2005; Adler, 1995).

Depending on the results obtained from the research; Studies about the effectiveness of Semantic Concept Maps in other teaching studies (in Other Life Science Themes) can be done. When the national and international literature is examined, it is seen that there are no or limited family education studies on the use of semantic concept maps. In this context, taking family opinions can contribute to the studies. It is seen that most of the studies conducted focus on the teaching process, and studies on the use of concept maps as an assessment tool are conducted in other fields. In parallel with this, it is thought that there is a need to carry out studies on the use of concept maps as an assessment tool in the field of special education.

\section{Acknowledgment}

This article has been produced and translated from the master's thesis titled "Otizm Spektrum Bozukluğu Olan Öğrencilere Kavram Öğretiminde Semantik Kavram Haritası Yönteminin Etkililiğı’”.

\section{References}

Adler, S. (1995). Helping Teachers Build Complex Conceptual Rameworks. In H. Ron \& S. Moshe (Eds.), Partnerships of Schools and Institutions of Higher Education in Teacher Development (pp. 85-100). Israeli Ben Gurion University of the Negev Press.

Aktepe, V., \& Yalçınkaya, E. (2016). Hayat bilgisi dersinde değer eğitimi ve uygulama örnekleri. Pegem Atıf Indeksi, 133-177. https://doi.org/10.14527/9786053185468.06

Alkahtani, K. (2009). Creativity Training Effects Upon Concept Map Complexity of Children with ADHD: An Experimental Study. Doctoral Dissertation, University of Glasgow.

Aziz, Z., \& Jair, N. (2009). Penggunaan peta konsep untuk meningkatkan pencapaian mata pelajaran sejarah bagi pelajar tingkatan dua (the use of concept maps in improving achievement in the subject of history for form two students). Malaysian Journal of Education, 34(1), 3-15.

Balım, A. G., Aydın, G., \& Evrekli, E. (2006). Fen ve Teknoloji Öğretiminde Zihin Haritaları ve Kavram Haritaları Kullanmanin Önemi (Vol. 19). In VI. International Educational Technologies Conference, Famagusta, Turkish Republic of Northern Cyprus, April.

Bilasa, P., Aladağ, S., Güven, S., Kaymakcı, S., Yontar, A., Kapıcı, H., ... Kuş, Z. (2016). Hayat Bilgisi Dersi Öğretim Programının Tarihsel Gelişimi. https://doi.org/10.14527/9786053185468.02

Birkan, B. (2009). Otizmi Olan Çocuklar ve Ĕ̆itimi, Genel Ĕ̆itim Okullarında Özel Gereksinimi Olan Öğrenciler ve Özel Eğitim (Gönül Akçamete Editör). Ankara: Kök Yayınları.

Brinkmann, A. (2007). Grafiksel Bilgi Gösterimi-Matematik Eğitiminde Etkili Araçlar Olarak Zihin ve Kavram Haritaları. Elementary Education Online, 6(1), 1-11.

Broun, T. L. (2004). Teaching Students with Autistic Spectrum Disorders to Read: A Visual Approch. Teaching Exceptional Children, 36(4), 36-40. https://doi.org/10.1177/004005990403600405

Canas, A. J., Carff, R., Hill, G., Carvalho, M., Arguedas, M., Eskridge, T. C., .. Carvajal, R. (2005). Concept Maps: Integrating Knowledge and İnformation Visualization. In Knowledge and Information Visualization (pp. 205-219). Springer, Berlin, Heidelberg. https://doi.org/10.1007/11510154_11

Chiou, C. C. (2008). The effect of concept mapping on students' learning achievements and interests. 
Innovations in Education and Teaching International, 45(4), 375-387. https://doi.org/10.1080/14703290802377240

Dettmer, S., Simpson, R. L., Myles-Smith B., \& Ganz, J. B. (2000). The Use of Visual Supports to Facilitate Transitions of Students with Autism. Focus on Autism and Other Developmental Disabilities, 15(3), 163-169. https://doi.org/10.1177/108835760001500307

Ersoy, A., \& Kılınç, M. (2013). Hayat bilgisi dersi öğretim programının etik bilinç geliştirme açısından öğretmen görüşlerine dayalı olarak değerlendirilmesi. Mersin Üniversitesi Eğitim Fakültesi Dergisi, 9(2), $109-126$.

Fisher, K. M. (1990). Semantic Networking: The New Kid on The Block. Journal of Research in Science Teaching, 27(10), 1001-1018. https://doi.org/10.1002/tea.3660271008

Girgin, M. (2006). Hayat Bilgisi ve Sosyal Bilgiler Öğretiminde Kavram İlke ve Genellemeler (pp. 23-54). Hayat Bilgisi ve Sosyal Bilgiler Öğretimi. İstanbul: Lisans Yayıncılık.

Grandin, T., \& İftar, M. C. (2005). Resimlerle Düşünmek: Otizmin İçerden Anlatımı. Doğan Kitap.

Güzel-Özmen, R. (2006). Uyarlanmış Bilişsel Strateji Öğretiminin Zihinsel Engelli Öğrencilerin Yazılı İfade Sürecinde Kullanılan Üstbilişsel Strateji Bilgisini Kazanmalarında Etkisi. Ankara Üniversitesi Ĕ̆itim Bilimleri Fakültesi Özel Ĕgitim Dergisi, 7(2), 49-66.

Güzel-Özmen, R. (2009). Hayat Bilgisi, Sosyal Bilgiler ve Fen Bilgisi Öğretiminde Öğrenme Güçlüğü Olan ve Zihinsel Yetersizlikten Etkilenmiş Öğrenciler İçin Şematik Düzenleyicilerin Oluşturulması ve Sunumu. Milli Eğitim Dergisi, 37(289), 289-301.

Huang, Y. C., \& Lee, I. J. (2020, July). Using augmented reality and concept mapping to improve ability to master social relationships and social reciprocity for children with autism Spectrum disorder. In International Conference on Human-Computer Interaction (pp. 19-37). Springer, Cham. https://doi.org/10.1007/978-3-030-49108-6_2

Ingec, S. K. (2008). Use of Concept Cartoons as an Assessment Tool in Physics Education. Online Submission, $5(11), 47-54$.

Jackson, E. M., \& Hanline, M. F. (2020). Using a concept map with RECALL to increase the comprehension of science texts for children with autism. Focus on Autism and Other Developmental Disabilities, 35(2), 90-100. https://doi.org/10.1177/1088357619889933

Janzen, J. E. (1996). Understanding the Nature of Autism: A Practical Guide. Psychological Corporation.

Jayaraman, N. (2009). Multivalent ligand presentation as a central concept to study intricate carbohydrate-protein interactions. Chemical Society Reviews, 38(12), 3463-3483. https://doi.org/10.1039/b815961k

Kabapınar, Y., \& Özkan, Ö. (2012). Hayatın bilgisine ilişkin deneyimler sunma boyutunda hayat bilgisi ders kitaplarındaki örnek olaylar ve işlevleri.

Kimball, J. W., Kinney, E. M., Taylor, B. A., \& Stromer, R. (2003). Using Engaging Computer-Cued Activity Schedules. Teaching Exceptional Children, 36(1), 40-45. https://doi.org/10.1177/004005990303600105

Kinchin, I. M. (2014). Concept mapping as a learning tool in higher education: A critical analysis of recent reviews. The Journal of Continuing Higher Education, 62(1), 39-49. https://doi.org/10.1080/07377363.2014.872011

Kırcaali-İftar, G., \& Tekin, E. (1997). Tek Denekli Araştırma Yöntemleri. Ankara; Türk Psikologlar Derneği.

Koçak, F. (2011). Otistik Çocuklara Hayat Bilgisi Dersi'ailemiz'teması İçinde Geçen Kavramların Öğretiminde Semantik (Anlamsal) Kavram Haritalarının Kullanımının Etkililiği. Selçuk Üniversitesi Eğitim Bilimleri Enstitüsü.

Lee, I. J., Chen, C. H., Wang, C. P., \& Chung, C. H. (2018). Augmented reality plus concept map technique to teach children with ASD to use social cues when meeting and greeting. The Asia-Pacific Education Researcher, 27(3), 227-243. https://doi.org/10.1007/s40299-018-0382-5

Maguire, A. (2005). Visual Strategies Leverage Autism's Strenght to Improve Lives. The Exceptional Parent, 35(4), 34-35.

Mcclannahan, L. E., \& Krantz, P. J. (1999). Activity Schedules for Children with Autism: Teaching independent Behavior. Woodbine House. 
MEB. (2009). İlköğretim 1, 2 ve 3. sinıflar hayat bilgisi dersi ögretim programı ve kllavuzu. Retrieved from http://tkb.meb.gov.tr/program2.aspx?islem=1\&kno=30 adresinden 25.10.2015 tarihinde alınmıştır.

Milli, E. B. (2004). İlkögretim Hayat Bilgisi (1.,2.,3. Sinuflar) Öğretim Programı. Anakara: Milli Eğitim Bakanlığı Yayınları.

Morris, E. K. (2009). A Case Study in The Misrepresentation of Applied Behavior Analysis in Autism: The Gernsbacher Lectures. The Behavior Analyst, 32(1), 205-240. https://doi.org/10.1007/BF03392184

Özyürek, M. (1984). Kavram Öğrenme ve Öğretme. Ankara Üniversitesi Eğitim Fakültesi Dergisi, 16(2), $347-366$.

Özyürek, M. (2009). Bilişsel ve Devimsel Davranışları Öğretmeyi Kazanma. İstanbul: Daktylos.

Patton, J. R., \& Bailey, J. W. (2013). Science Strategies for Teaching Learners with Special Needs (Eds., Polloway, E. A. Patton, J. R., Serna, L., \& Bailey, J. W.) (10th ed.). Boston: Pearson.

Rao, S. M., \& Gagie, B. (2006). Leraning Through Seeing and Doing Visual Supports for Children with Autism. Teaching Exceptional Children, 38, 26-33. https://doi.org/10.1177/004005990603800604

Ruiz - Primo, M. A., \& Shavelson, R. J. (1996). Problems and Issues in The Use of Concept Maps in Science Assessment. Journal of Research in Science Teaching: The Official Journal of The National Association for


https://doi.org/10.1002/(SICI)1098-2736(199608)33:6<569::AID-TEA1>3.0.CO;2-M

Şahin, M. (2009). Cumhuriyetin Kuruluşundan Günümüze Türkiye'de Hayat Bilgisi Dersi Programlarının Gelişimi. Journal of International Social Research, 2(8).

Şen, A. İ., \& Koca, S. A. Ö. (2003). Kavram Haritalarının Analizinde Niceliksel ve Niteliksel Metotların Kullanımı ve Karşılaştırılması. Çukurova Üniversitesi, Eğitim Fakültesi Dergisi, 2, 1-9.

Şimşek, A. (2006). Kavramların Öğretimi (A. Şimşek Edt., pp. 27-70). İçerik Türlerine Dayalı Öğretim.

Sucuoğlu, B. (2010). Zihin Engelliler ve Eğitimleri. Ankara Üniversitesi Eğitim Bilimleri Fakültesi Özel Eğitim Dergisi, 8(02), 88-90.

Tekin-İftar, E., \& Değirmenci, H. D. (2014). Otizm Spektrum Bozukluğu Olan Çocukların Öğretimi. Otizm Spektrum Bozukluğu Olan Çocuklar ve Ĕgitimleri, 267-313.

Vadlapatla, R., Kaur, S., \& Zhao, Y. (2014). Evaluation of student perceptions of concept mapping activity in a didactic pharmaceutics course. Currents in Pharmacy Teaching and Learning, 6(4), 543-549. https://doi.org/10.1016/j.cptl.2014.04.014

Vayiç, Ş. (2008). Zihinsel Yetersizlikten Etkilenmiş Öğrencilere Hayat Bilgisi Öğretiminde Doğrudan Öğretim Yöntemi ve Şematik Düzenleyiciyle Öğretimin Karşılaştırılması. Yayınlanmamış Yüksek Lisans Tezi, Gazi Üniversitesi Eğitim Bilimleri Enstitüsü, Ankara.

Yıldız, S. Ş. (2009). 2005 Hayat Bilgisi Dersi Öğretim Programının Birleştirilmiş Sinıflarda Uygulanabilirliğinin Ögrretmen Görüşlerine Göre Değerlendirilmesi (Nitel Bir Araştırma). Master's thesis, Afyon Kocatepe Üniversitesi, Sosyal Bilimler Enstitüsü.

\section{Copyrights}

Copyright for this article is retained by the author, with first publication rights granted to the journal.

This is an open-access article distributed under the terms and conditions of the Creative Commons Attribution license (http://creativecommons.org/licenses/by/4.0/). 